\title{
The Concept of Persons in Kant and Fichte*
}

\begin{abstract}
Owen Ware
Beings whose existence rests not on our will but on nature, if they are nonrational

beings, still have only a relative worth as means, and are therefore called things,

whereas rational beings are called persons because their nature already marks them out as an end in itself.

-KANT, Groundwork for the Metaphysics of Morals (1785)
\end{abstract}

\section{INTRODUCTION}

One of Kant's most famous and celebrated declarations in the Groundwork for the Metaphysics of Morals (1785) is that one ought always to treat persons as ends in themselves and never as mere means. ${ }^{1}$ Surprisingly, the ontological status of persons in Kant's moral philosophy has gone largely overlooked by scholars, despite the fact that this status is visible in his remark that persons are "marked out" as ends, and thereby distinguished from things, due to their "nature" (Natur). ${ }^{2}$ Once one shifts attention to the nature of persons in his theoretical philosophy, there is evidence to suggest that Kant maintains core

\footnotetext{
* For feedback on earlier versions of this chapter, I would like to thank René Brouwer, Anthony Bruno, Johannes Haag, Dai Heide, Karolina Hübner, Antonia LoLordo, Colin Marshall, Allen Wood, and Ariel Zylberman, as well as audience members at Indiana University.

I Citations of Kant refer to the Gesammelte Schriften, ed. Deutsche (formerly KöniglichPreussische) Akademie der Wissenschaften. (Berlin: de Gruyter, 1900-). Translations are my own.

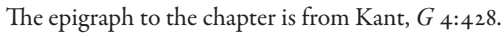

2 Kant, $G 4: 428$.
} 
views of the rationalist school-from Leibniz, Descartes, and their scholastic predecessors - for whom persons are individual substances endowed with intrinsic properties. ${ }^{3}$ Though Kant subjects these views to a rigorous critique, denying their status as strong knowledge claims, he continues to affirm that a broadly scholastic account of persons follows from the concept of the "I" and so remains analytically true. ${ }^{4} \mathrm{My}$ aim in this chapter is to examine Kant's ontological model of persons and its eventual transformation in the hands of his early successor, J. G. Fichte.

2 Persons in Kant's Theoretical Philosophy 2.I "I Think": Kant's Critique of Rational Psychology

On first glance what Kant has to say about the ontological model of persons is largely, if not entirely, negative. In the Critique of Pure Reason (1781/87), for example, one finds a separate chapter devoted to the fallacious errors (termed "paralogisms") that beset the rational

3 While this philosophical tradition has roots in Aristotle, Boethius is one of the first thinkers to define a person explicitly in these terms: "Wherefore if person belongs to substances alone, and these rational, and if every substance is a nature, and exists not in universals but in individuals, we have found the definition of person: 'The individual substance of a rational nature' [naturae rationabilis individua substantial]." The Theological Tractates, trans. H. F. Stewart, E. K. Rand, and S. J. Tester (Cambridge, MA: Harvard University Press, 1973), 85. Kant's association of the "dignity" of persons and their "self-subsisting existence" also has a clear precedent in Aquinas, who writes: "Now, the nature which person includes in its signification is the most worthy [dignissima] of all natures, namely, the intellectual nature according to its genus; and likewise the mode of existing signified by person is the most worthy [dignissimus], namely, such that something be existing by itself [per se existens]." Quaestiones Disputatae de Potentia Dei, trans. English Dominican Fathers (Maryland: Newman Press: 1952), q. 9, a. 3, corp). Thanks to Martin Pickavé and Peter King for conversations on this material. For fuller treatments of the pre-Kantian context, see Theo Kobusch, Die Entdeckung der Person: Metaphysik der Freibeit und modernes Menschenbild (Freiburg: Herder, 1993), as well as chapters 2 and 6 here.

4 Depending on the context, Kant's definition of a person changes, meaning either ( $\mathrm{I}$ ) intelligence (rational nature as such), (2) autonomy (moral self-determination), or (3) personal identity (continuity of self-consciousness over time). In some places he argues for a connection between two or all three (see Refl 4225; MS 6:223; and Anth 7:127). However, because Kant also speaks of personal identity and moral autonomy as specific attributes of persons, I shall employ the first (more general) sense in this chapter. For further discussion, see Georg Mohr, "Der Begriff der Person bei Kant, Fichte und Hegel," in Philosophiegeschichte-Theoretische Philosophie-Praktische Philosophie, ed. Dieter Sturma (Münster: Mentis, 200I). 
psychologist, and Kant's task is to trace these errors to a common root. The mistake is to assume that by attending carefully to the "I think" of self-consciousness one can somehow access the nature of the soul, that human beings are simple substances, identical over time, and immaterial. ${ }^{5}$ The cause of this mistake, Kant explains, is that anyone reflecting on the I is exposed to an illusion: that the subjective conditions for thinking about oneself appear to be objective conditions for one's existence. ${ }^{6}$ Deceived by this illusion, the rational psychologist assumes that the concepts necessary for thinking of the I-substantiality, simplicity, identity, and immateriality-support strong knowledge claims about the inner constitution of persons. Yet once this illusion is exposed, the insight one is left with is that such concepts have only subjective validity. They "cannot teach us any of the ordinary conclusions of the rationalistic doctrine of the soul," Kant explains, "such as, e.g., the everlasting duration of the soul through all alterations, including the human being's death."7 This is the basic lesson of the Paralogisms.

But just how deflationary is the lesson supposed to be? On the one hand the result Kant appears to be seeking is that all claims about the true nature of persons are empty. Once one realizes that cognition requires intuition, and that intuition (at least for human beings) is subject to the conditions of space and time, Kant thinks it should be clear why the project of knowing one's inner constitution is hopeless. As he argues, the intrinsic properties of the soul the rational psychologist purports to apprehend are nothing more than "pure categories, through which I never think a determinate object, but rather only the unity of representations." Remarks like this suggest that Kant aims to curtail claims about persons to their phenomenal status (as they appear in space and time), and thereby denounce as meaningless all assertions

\footnotetext{
5 Kant, $\mathrm{A}_{345} / \mathrm{B}_{4} \mathrm{O}_{3}$.

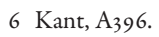

7 Kant, $\mathrm{A}_{350-35 \mathrm{I} .}$

8 Kant, A399.
} 
about persons in their noumenal status (as they exist outside space and time). Kant even says that when philosophers look at the doctrine of the soul more closely, "we can place nothing but the simple and in content for itself wholly empty representation I" at its basis, "of which one cannot even say that it is a concept, but a mere consciousness that accompanies every concept. Through this I, or He, or It (the thing), which thinks, nothing further is represented than a transcendental subject of thoughts $=x{ }^{\prime \prime} 9$ Beyond this it seems there is nothing more that can be said.

On the other hand there are passages indicating that Kant is more permissive in his view of what humans can know about their noumenal status. A striking example appears later in the first Critique when Kant considers what human beings can say about themselves through pure self-consciousness or what he calls "pure apperception":

In lifeless nature and nature having merely animal life, we find no ground for thinking of any faculty which is other than sensibly conditioned. The human being alone, who is otherwise acquainted with the whole of nature only through sense, cognizes himself [erkennt sich selbst] also through mere apperception, and indeed in actions and inner determinations which cannot at all be counted among the impressions of sense. He is admittedly in one part phenomenon, but in another part, namely in regard to certain capacities, a merely intelligible object, because the actions of this object cannot at all be ascribed to the receptivity of sensibility. We call these capacities understanding and reason. ${ }^{10}$

Upon reading passages like this, one might wonder how Kant is entitled to speak of the "merely intelligible" side of human nature, given everything he has said in the Paralogisms. Apprehending oneself as a

\footnotetext{
9 Kant, $\mathrm{A}_{346 .}$

Io Kant A546-547/B $574-575$.
} 
noumenal person on the basis of pure apperception seems to be the very ambition of rational psychology, and Kant has already shown that this ambition rests on a deceptive illusion. Humans cannot secure strong knowledge claims about themselves through reflection on the I, because reflection on the I yields no corresponding intuition-and without intuition, we have no basis for cognition. Is Kant then not guilty of a contradiction here?

My view is that the answer depends on how one characterizes the real target of the Paralogisms. ${ }^{11}$ If Kant is targeting all claims about persons in themselves, then arguably he would be guilty of inconsistency, denying knowledge of humans' noumenal status in the first instance, and then asserting such knowledge later in the book. Yet there are indications that Kant's initial aim is more modest, and that what he is targeting in the Paralogisms is not claims about noumenal persons in general but the synthetic claims made by the rational psychologist in particular. ${ }^{12}$ A clue to this line of interpretation occurs when Kant writes: "If anyone were to pose the question to me, 'Of what is the constitution of a thing that thinks?' then I do not know the least a priori to answer, because the answer should be synthetic (for an analytic answer perhaps explains thinking, but gives no extended cognition)." ${ }^{13}$ The mistake of the rational psychologist is to assume, for example, that the pure concept of substance extends cognition to the I qua noumenon, yielding determinate insight into one of its intrinsic properties. Curtailing

II There is an excellent new body of literature on this topic. See Eric Watkins, Kant and the Metaphysics of Causality (Cambridge: Cambridge University Press, 2005); Karl Ameriks, "The Critique of Metaphysics: The Structure and Fate of Kant's Dialectic," in Kant and Modern Philosophy, ed. Paul Guyer (Cambridge: Cambridge University Press, 2006), 269-302; Colin Marshall, "Kant's Metaphysics of the Self," Philosophers' Imprint Io (2010): I-2I; Julian Wuerth, "The Paralogisms of Pure Reason," in The Cambridge Companion to Kant's Critique of Pure Reason, ed. Paul Guyer (Cambridge: Cambridge University Press, 2010), 210-244; Christopher J. Insole, Kant and the Creation of Freedom (Oxford: Oxford University Press, 2013); Corey W. Dyck, Kant and Rational Psychology (Oxford: Oxford University Press, 2014); and Nicholas Stang, Kant's Modal Metaphysics (Oxford: Oxford University Press, 2016). I have also benefited from many fruitful conversations with Dai Heide.

I2 See Wuerth, "The Paralogisms of Pure Reason," 2II.

13 Kant, $\mathrm{A}_{39} 8$. 
this theoretical pretension does not jettison all claims about noumenal persons, one could argue, since it leaves untouched claims of an indeterminate scope. On this way of reading of the text, Kant's subsequent talk of knowing ourselves through pure apperception does not necessarily commit a fallacy, at least not if one reads it as a general statement about things in themselves. ${ }^{14}$

There is also textual evidence showing that Kant relies on weak knowledge claims about things in themselves into his Critical period, especially when he attacks the substance monism of Spinoza-whose system I shall return to later. In lecture transcripts dating from the midI 780 s, Kant accuses Spinoza of proceeding from a faulty definition of a substance as that which does not require the existence of anything else. On the basis of this definition Spinoza infers correctly that all individual things, including ourselves, are not finite substances at all, but accidents inhering in one infinite substance, a "whole of reality" (omnitudo realitatis) he calls "God." 15 But Kant thinks that one has no reason to accept this inference when one develops a proper definition of a substance as that which exists for itself "without being a determination of any other thing." ${ }^{16}$ Following this, Kant goes on to defend humans' status as finite substances on the basis of pure apperception, and what he says is telling:

The consciousness of myself testifies that I do not relate all my actions to God as the final subject which is not the predicate of any other thing, and thus the concept of a substance arises when I perceive in myself that I am not the predicate of any further thing. For example, when I think, I am conscious that my I, and not some other thing, thinks in me. I infer therefore that this thinking in me does

\footnotetext{
I4 See Wuerth, "The Paralogisms of Pure Reason," 211.

Is Kant, $P R$ 28:104I-1042. See A572/B600-A582/B610 for Kant's brief but highly suggestive account of how the omnitudo realitatis still admits of a regulative use in philosophers' search for systematic unity in nature.

16 Kant, $P R$ 28: 104I-1042.
} 
not inhere in another thing outside me but in myself, and consequently also that I am a substance, i.e., that I exist for myself, without being the predicate of another thing. I myself am a thing and hence also a substance. ${ }^{17}$

As with his claim in the first Critique that a human being apprehends himself through pure apperception, what Kant may be saying here is that by reflecting on the I, one can know in some metaphysical sense what one is not, that is, that one is not accidental, composite, plural, and so forth. ${ }^{18}$ And while that still leaves open the question of the soul's survival after the human being's death, it is seemingly weighty enough to block Spinoza's dangerous idea that humans are not noumenal persons but mere modes of an all-encompassing divinity. ${ }^{19}$

\subsection{The Transcendental Unity of Apperception}

The question of whether Kant's first Critique permits anything like a theory of noumenal persons has become a topic of controversy in recent years, and from the sketch I have offered it is easy to see why. However, despite the extensive literature Kant's account has now generated, few commentators pause to consider his argument that the theorems of rational psychology follow from the unity of self-consciousness and so enjoy the status of analytic truths. In this connection one finds Kant asking: "But what sort of use am I now to make of this concept of a substance? That I, as a thinking being, endure for myself, that naturally I neither arise nor perish? This I can by no means infer." ${ }^{20}$ Soon afterward he adds a more positive remark,

\footnotetext{
17 Kant, PR 28: 1041-I042; emphasis added. See also Refl 6275.

I8 See Wuerth, “The Paralogisms of Pure Reason," 2 II.

I9 See Karl Ameriks, "Idealism and Kantian Persons: Spinoza, Jacobi, and Schleiermacher," in Kant's Elliptical Path (Oxford: Oxford University Press, 20I2), I2O-142, for a penetrating treatment of this issue, to which I am much indebted.

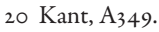


that "one can quite well allow the proposition The soul is substance to be valid, if only one admits that this concept of ours does not at all lead further... [and] that it denotes a substance only in idea but not in reality." ${ }^{21}$ While the main thrust of such passages is critical, Kant still believes that the substantiality of the soul, falsely arrogated as a synthetic claim by the rational psychologist, is logically true about one's representation of the I. And the same holds, he believes, for the other pure categories: "Now mere apperception ('I') is substance in concept, simple in concept, etc., and thus all these psychological theorems are indisputably correct."22

While this claim is integral to Kant's philosophy as a whole, his explicit argument for it is rather elusive. As the cited passage shows, Kant is assuming the reader's familiarity with his earlier principle of the "transcendental unity of apperception," according to which my representations are only possible to the extent that I can ascribe them to myself. ${ }^{23}$ What the apperception principle is meant to show is that the unity of my representations rests on the unity of the "I think" attending my representations. Or, as Kant puts it, it is only because "I can combine a manifold of given representations in one consciousness that it is possible for me to represent the identity of the consciousness in these representations itself," to which he adds: "otherwise I would have as multicolored, diverse a self as I have representations of which I am conscious." ${ }^{24}$ Among the many insights Kant thinks one acquires from the apperception principle, the one relevant to his discussion of the Paralogisms is that the Cartesian or Leibnizian is in some sense right. The I is "substance" in concept, to take one case, because I must represent myself as the subject of my thoughts and not as their predicate. In reflecting on myself, I am justified to think of myself as a substance

\footnotetext{
21 Kant, A350-351.

22 Kant, A400; emphasis added.

23 Kant, Bi31-I32; see also Aio7-108.

24 Kant, Bi34.
} 
(and so I have no reason to think of myself as an accident inhering in another substance, as Kant thinks Spinozism absurdly concludes).

This much is now clear. As pure categories for thinking of the transcendental unity of apperception, substantiality, simplicity, identity, and immateriality are "indisputably correct," even though they teach humans nothing determinate about their inner constitution. What is less clear, however, is Kant's argument for thinking of the apperception principle exclusively through the medium of these four categories. When one returns to the details of the text for an answer, it is surprising how little Kant says on the topic. One revealing stretch of text appears in the section of the first Critique where Kant divides the paralogisms into a table. When one attends to the paralogisms more closely, he explains, "one notes that apperception is carried through by all classes of categories, but only toward those concepts of the understanding which underlie the ground of unity [Grunde der Einheit] of the remaining ones in their class in a possible perception, consequently: subsistence, reality, unity (not plurality), and existence." 25 According to this progression, Kant is saying that my efforts to cognize myself yield four analytic truths about the I, truths one can affirm without succumbing to the errors of rational psychology. They are:

(I) That "I" am subsisting and not inhering;

(2) That "I" am simple and not composite;

(3) That "I" am identical and not numerically different over time; and finally,

(4) That "I" exist independently of what I represent in space, including my body. ${ }^{26}$

While Kant does not discuss this point further, it is worth stopping to ask why the subject attempting to apprehend itself only employs these

25 Kant, $\mathrm{A}_{4} 03$; emphasis added.

26 Kant, $\mathrm{A}_{4} 03$. 
categories. When one goes back and inspects all twelve categories Kant listed earlier in the first Critique-at A80/Bio6-one can see right away that, with the exception of modality, the theorems of rational psychology rest on the first-level concepts:
I. Quantity
II. Quality
III. Relation
IV. Modality
I. Unity
I. Reality
I. Subsistence
I. Possibility
2. Plurality
2. Negation
2. Causality
2. Existence
3. Totality
3. Limitation
3. Community
3. Necessity

Considering this rich array of options, the initial question I posed becomes all the more pressing. Why does Kant think the subject seeking to apprehend itself only employs "substance" under the heading of relation, "reality" under the heading of quality, "unity" under the heading of quantity, and "existence" under the heading of modality? Kant gives the reader no indication for thinking that his restriction is problematic, but this will prove to be a crucial dividing line for the early post-Kantians, as I shall show.

Hints of an argument for Kant's restriction appear when he writes that "apperception is carried through by all classes of categories [in seeking to apprehend itself], but only toward those concepts of the understanding which underlie the ground of unity of the remaining ones." ${ }^{27}$ Yet this argument suffers from at least one shortcoming. For when one stops to inspect the table of categories more carefully, it is evident that the concepts belonging to the third level play a special role, that of unifying the other two. Kant brings this role to the foreground in the Prolegomena to Any Future Metaphysics (1783) when he says that the third concept "springs from the first and second combined [verbunden] in one concept," 28 a point one finds later in the 1787 edition of the first Critique: "the third category always springs from

27 Kant, $\mathrm{A}_{4} \mathrm{O}_{3}$.

28 Kant, Prol 4:326n. 
the combination [Verbindung] of the first two in its class." ${ }^{29}$ Granted, these comments are not illuminating in so abstract a formulation, but the key point for my purposes is this. When one shifts attention from the first-level concepts (which constitute the "ground of unity" for the others) to the third-level concepts (which "combine" the first two in their class), a new possibility opens up. One now has the option of approaching the concept of the I, not only through the categories of substance, reality, unity, and existence, but also through the categories of community, limitation, totality, and necessity. A version of this insight will be central to the transformation of the apperception principle in the hands of Fichte, to whom I now turn. ${ }^{30}$

\section{Persons in Fichte's Theoretical Philosophy}

\section{I "I Am": Fichte's Doctrine of Science}

I speak of a version of this insight because post-Kantians like Fichte do not simply reverse Kant's progression of categories in approaching the concept of a person. Yet what is clear is that by the time of

29 Kant, Biro. That is, "community" is the causality of a substance in reciprocal interaction with others; "limitation" is the negation of a reality; "totality" is plurality considered as a unity; and "necessity" is existence given by possibility itself (B⿵⺆). We find a similar claim in the Groundwork when Kant writes: The above three ways of representing the principle of morality [1. the Formula of Universal Law, 2. the Formula of Humanity, and 3. the Formula of Autonomy] are fundamentally only so many formulae of the same law, one of which [i.e., the Formula of Autonomy] unites the other two within itself [deren die eine die anderen zwei von selbst in sich vereinigt] ( $G_{4}: 436$; emphasis added).

30 As is well known, Kant rewrote the Paralogisms chapter for the 1787 edition of the first Critique. But it remains difficult to say just how much the new version alters the substance of the original, or merely its mode of presentation. One thing worth observing is that the new version still insists on the analytic or conceptual validity of the four theorems of rational psychology, though Kant's language is more careful. He says, for example, that "the I that I think can always be considered as a subject ... but this does not signify that I as object am for myself a self-subsisting being or substance" $\left(\mathrm{B}_{4} 07\right)$. In other words, he restricts the scope of "substance" in the new version to the particular sense employed (synthetically) by the rational psychologist, whereas in the original version "substance" is employed (analytically) as the concept of a subject distinct from predicates

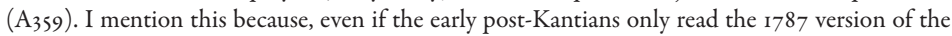
first Critique, they still would have been struck by Kant's restriction of concepts applicable to the "I." Thanks to Allen Wood for pressing me on this issue. 
Fichte's works, any trace of the idea that a finite noumenal substance lies behind "the thing that thinks" has vanished. And in its place one finds a complex attempt to rework Kant's table of categories around the transcendental unity of self-consciousness, starting with an account of how "the I exists and comes into being for itself." ${ }^{31}$ Here Fichte wants to convince his readers that true philosophical inquiry must have this starting point, and in saying this he does not mask his debt to Kant for separating what is empirical in self-consciousness from what is pure. This distinction lies at the center of his "Doctrine of Science" (Wissenschaftslebre), which he introduced to the intellectual public in 1794 and continued to rework until the end of his life. ${ }^{32}$ Its basic, if cryptic stipulation is that if one wants to secure a "derivation of consciousness as a whole" - the equivalent, in Fichte's view, to a philosophical system - then there is only one place one should begin. One should begin with a version of the apperception principle, "with the pure I-which is precisely how the Wissenschaftslehre does begin-and the idea of such a science has already been provided by Kant himself." 33

When one enters Fichte's Doctrine of Science for the first time, in any of its early versions, it is difficult to see the extent to which his concept of a "pure I" adds anything new to the apperception principle. In his second introduction to the Foundation of the Entire Wissenschaftslehre, for example, Fichte appeals to Kant's claim that the unity of my representations rests on the unity of the "I think" attending my representations, asking: "Which 'I' is being spoken of here?"34 In his view the answer becomes clear when Kant writes that

31 Fichte, ZWEL I:458. Citations of Fichte refer to Fichtes Werke, ed. Immanuel Hermann Fichte, ir vols. (Berlin: de Gruyter, 1971). Translations are my own.

32 I shall be focusing mainly on the 1794 Wissenschaftslehre. For two compelling treatments of the unity of Fichte's early of Science, see Daniel Breazeale, "The Spirit of the Wissenschaftslebre," in Thinking through the Wissenschaftslehre: Themes from Fichte's Early Philosophy (Oxford: Oxford University Press, 2014), 96-I23; and Allen W. Wood, Fichte's Ethical Thought (Oxford: Oxford University Press, 2016).

33 Fichte, $Z W E L$ 4:477.

34 Fichte, $Z W E L$ 4:475. 
pure apperception "must be able to accompany all other representations" and is therefore "one and the same" in all consciousness. ${ }^{35}$ What this entails is that pure apperception is not determined by anything contingent, anything that would pertain to the empirical consciousness of my individuality. Accordingly, Fichte argues, what is pure in self-consciousness must be "determined solely by itself." ${ }^{36}$ And what is determined solely by itself is the absolute activity of the I, which is the first principle of his Doctrine of Science. On this basis Fichte concludes that one finds "quite definitely" in Kant "the concept of the pure I, exactly as it is set up in the Wissenschaftslehre." ${ }^{7}$ Yet the textual evidence is not so straightforward. For when one enters more deeply into Fichte's writings at the time, a number of contrasts between his position and Kant's come into view.

The first and most obvious of these contrasts is that Fichte turns to a version of the apperception principle from a conviction that "philosophy until now has been devoid of a highest, universally valid first principle, and only after establishing one will philosophy be able to raise itself to the level of a science." ${ }^{38}$ This is the promise the Wissenschaftslehre holds out. If one wants a philosophical system, one must begin with a universally valid first principle, that is, a principle that is itself unconditioned by any higher principle. At this point, when every possible option is considered, Fichte thinks one must see that only one candidate presents itself with absolute certainty: namely, that I am active in positing myself, that "I am I." What this formulation shows is that Fichte's first principle is not a mere "fact" (Thatsache) of consciousness, something one could discover through introspection alone, but an original "fact/act" (Thathandlung) of the I. ${ }^{39}$ Interestingly, Fichte

\footnotetext{
35 Kant, B132.

36 Fichte, $Z W E L_{4: 476 .}$

37 Fichte, $Z W E L$ 4:476.

38 Fichte, $R A$ I:4.

39 Fichte, GWL I:96.
} 
also asserts that the best term philosophers have to characterize one's access to this act is "intellectual intuition," not because one can employ a category to a nonspatial/nontemporal thing, but because one is aware of the self-positing of the I without the mediation of concepts. Nowhere in Kant does the apperception principle play this privileged role, despite its importance for his theoretical philosophy.

That being said, the real novelty of Fichte's position comes into focus when one considers the implications these departures have, each of which bears upon his concept of a person. In the first place, Fichte thinks that if we take his founding principle seriously_that I am active in positing myself, that "I am I"-then one must see that all further talk of something beyond the I is problematic. For one must ask: What meaning could philosophers assign to the concept of a "not-I" (as a brute given) once they concede that all certainty rests on the I and its original activity? Of course, if we disregard this thought and assign absolute reality to something beyond the I, then we would effectively make the not-I into a higher principle-but that, Fichte points out, would contradict our initial insight: that only the I has claim to the status of a first principle. How then can we proceed with consistency? The preliminary answer Fichte gives is that the not-I cannot be a wholly independent concept, which is to say that the not-I must acquire its positive determination in relation to the I itself. ${ }^{40}$ Now if we accept this further point, that the I and the not-I must stand in relation to each other, Fichte thinks it is obvious that the idea of a "thing in itself [Ding an sich], to the extent that this is supposed to be a not-I not opposed to any I, is self-contradictory." ${ }^{1}$

The steps leading up to Fichte's rejection of the thing in itself are more subtle than I have described, but their general outline should be clear. By responding to the demand that philosophy have one universally valid and self-evident principle, and by identifying this principle 
with the absolute Thathandlung of the I, Fichte comes to the conclusion that all talk of something bearing no connection to the I is unintelligible. From the standpoint of his Doctrine of Science, as a result, all talk of things endowed with intrinsic properties-the individual substance of rational psychology, for instance-ceases to make sense. After all, the concept of an intrinsic property is the concept of something one can think of independently of its relation to anything else, that is, something one can think of in total isolation. In the tradition of Descartes and Leibniz, as I have shown, a "person" is supposed to be thinkable in precisely this way, as a monadic entity whose basic features are intelligible without a nexus of relations, including a nexus of relations to other monadic entities. From the standpoint of Fichte's Doctrine of Science, one is then in a position to say that the mistake of rational psychology occurs at a deeper level than Kant ever diagnosed in the Paralogisms. It is not the mistake of seeking to extend cognition to a person in itself, but the mistake of assuming that a person is even thinkable in total isolation. In Kant's own terms, the mistake is not synthetic, but analytic.

\section{2 "I" and "Not-I": The Priority of Relation}

One far-reaching implication of Fichte's rejection of the thing in itself is that all thinking must be governed by the category of relation, includingphilosophical reflection on the I and its absolute activity. ${ }^{42}$ Indeed, the priority of the category of relation underpins his entire Doctrine of Science and is without a doubt a leitmotif for the first post-Kantians,

42 Writing just after the publication of Fichte's 1794 Wissenschaftslehre, Schelling says: "If one observes the Kantian Table of these forms more closely, then one actually finds that Kant, instead of placing the original form [Urform] as the principle for all the others, posited it among the others in the same series. For on closer examination one readily sees that the forms of relation are not only the ground [Grunde] for all the others, but are actually identical with the original form (the analytic, the synthetic, and the two combined)" (FP I:107). Citations of Schelling refer to Schellings Sämmtliche Werke, ed. Karl Friedrich August Schelling, I2 vols. (Stuttgart: Cotta, I856). Translations are my own. 
including Schelling, Schiller, Schleiermacher, ${ }^{43}$ and Hegel. What is more, Fichte interprets Kant's remark cited earlier, that the "third category always arises from the combination of the first two in its class," ${ }^{4}$ as evidence that "community" (Gemeinschaft) or "reciprocal interaction" (Wechselwirkung) is not on a par with the others but is rather the "category of all categories." 45 "Substantiality and causality are coordinated with each other," he writes, "but both are subordinated to the category of reciprocal interaction." ${ }^{46}$ In Fichte's view the import of this priority is clear: "We can think of nothing but relations." ${ }^{47}$ All of this explains why it would be a mistake to think of Fichte's first principle of the I as a self-contained principle. Guided by the category of relation, Fichte maintains that one cannot think of the I on its own without simultaneously positing a not-I-and this introduces his second principle, the principle of opposition. Going further still, he argues that both the I and the not-I must determine each other mutually-and this introduces his third principle, the principle of interdetermination. Thus Fichte's whole argument is of a relational character, since the intelligibility of the I is connected inseparably to the not-I and vice versa. $^{48}$

When one examines how Fichte sets up this triad of principles, particularly in the 1794 Wissenschaftslehre, it becomes clear that his concept of a pure I is not a direct transposition of Kant's apperception principle. In fact, not long after introducing the concept of the I in this

\footnotetext{
43 See Jacqueline Mariña, Transformation of the Self in the Thought of Schleiermacher (Oxford: Oxford University Press, 2008) for an outstanding treatment of this topic.

44 Kant, Biro.

45 Fichte, WLnm 212. These passages come from the Wissenschaftslehre nova methodo, ed. Erich Fuchs (Hamburg: Meiner, 1994), originally student transcripts of Fichte's private lectures during the late 1790 .

46 Fichte, WLnm 212.

47 Fichte, WLnm 212.

48 Fichte, GWL 1:104-108. In what follows I am indebted to Paul Franks's discussion in All or Nothing: Systematicity, Transcendental Arguments, and Skepticism in German Idealism (Cambridge, MA.: Harvard University Press, 2005). See in particular Franks, All or Nothing, 85 note 2, 251, and 253 .
} 
work, Fichte tells his readers that in saying "the I determines itself" he means to ascribe to it an "absolute totality of the real" (absolute Totalität der Realität). ${ }^{49}$ Similar remarks appear with greater frequency in the text, and at one point Fichte even defines the category of substance in openly Spinozistic terms: "Insofar as the I is regarded as encompassing the whole, absolutely determined realm of all realities," he writes, "it is substance"; 50 and a few sentences later: "It is initially only One substance, the I; within this One substance, all possible accidents, and so all possible realities, are posited." 51 In this way Fichte's pure I bears a conspicuous affinity to the "whole of reality" (omnitudo realitatis) which is characteristic of Spinoza's infinite substance, of which all individual parts are mere "limitations." 52 This is a far cry from the model of persons Kant carries over from the scholastic tradition, according to which the I of the thing who thinks refers (at least negatively) to a monadic entity. Nor does Fichte hide the fact that by reframing the I in terms of a totality of the real, as an omnitudo realitatis, he is following in the footsteps of Spinoza. At one point he even claims, rather boldly, that his Doctrine of Science is "Spinozism made systematic." 33

49 Fichte, GWL 1:129.

50 Fichte, GWL I:142.

51 Fichte, GWL I:142. Schelling echoes this definition in 1795 when he writes: "If substance is the unconditional, then the I is the only substance," playing on Spinoza, Ethics ipi4: "Except God, no substance can be or be conceived"; Ethics, in Collected Works of Spinoza, ed. Edwin Curley (Princeton: Princeton University Press, 1984). In this vein Schelling continues: "Were there several substances, there would be an I outside the I, which is nonsensical” (IP I:192). Of course, the extent to which this captures Spinoza's own position is highly contentious, but this question raises interpretive issues that go beyond the scope of my chapter.

52 Fichte, GWL I:137.

53 Fichte, $G W L$ i:122. In a recent essay Jakub Kloc-Konkołowicz has identified-accurately, in my view-a "kritischen Monismus der Vernunft" in Fichte's theoretical philosophy: "It should belike in Spinoza's - a monism, but a monism grounded, not on a given unity, but rather on an aspired unity [einer angestrebten Einheit]"; "Der Kantische Spinozismus: Die Gegenwart Spinozas in der Sittenlehre Fichtes," Fichte-Studien 27 [2006]: 38. A version of this insight was anticipated in the nineteenth century by Charles Carroll Everett, who wrote: "We can now understand how the position of Fichte differs at this point from that of Spinoza. With Spinoza, all beings are one with God; with Fichte, they tend to become so"; Fichte's Science of Knowledge: A Critical Exposition (Chicago: Griggs, 1884), 256. 
More often than not Fichte is at pains to show where Spinoza is wrong, but these points of criticism often hint at a similarity in their views. Quite early in the Wissenschaftslehre, for example, Fichte writes:

On his [Spinoza's] view the entire series of representations in an empirical subject is related to the one pure subject as a single representation is to a series. For him the "I" (what he calls his I, or what I call mine) does not exist absolutely because it exists, but because something else exists.-The I for him is indeed an I for itself, but he asks what it would be for something other than the I. Such an "other than I" would equally be an I, of which the posited I (e.g. my I) and every other that could be posited [i.e., other I's] would be modifications. $^{54}$

In this passage Fichte explains that Spinoza "does not deny the unity of empirical consciousness, but he completely denies [the unity of] pure consciousness," ${ }^{5}$ and that, in his view, is Spinoza's fatal mistake and the reason why his system is a form of dogmatism. To be sure, when one reads statements like this one might think that Fichte is siding with Kant's claim that "when I think, I am conscious that my I, and not some other thing, thinks in me" 56 - that is, that through pure apperception I am aware of existing for myself, as the subject of my thoughts, and not as a predicate inhering in something else. Yet on closer inspection one can see that what Fichte finds problematic with Spinoza's position is not that it entails the rejection of a plurality of finite substances (and our status as noumenal persons) but that it characterizes the one infinite substance as something opposed to the I rather than as the pure I itself. So when he writes that a not-I "would equally be an I, of which

\footnotetext{
54 Fichte, $G W L$ I:102.

55 Fichte, $G W L$ i:100.

56 Kant, $P R$ 28:1041.
} 
the posited I (e.g. my I) and every other that could be posited [i.e., other I's] would be modifications," Fichte is, I believe, giving the reader a key for understanding his positive view in the Doctrine of Science. On this reading Fichte has no qualms with the omnitudo realitatis of Spinoza's monism; he merely wants to relate this omnitudo realitatis to the I, as he thinks a philosophical system demands of us.

This marks a pivotal moment in Fichte's analysis, since he recognizes that the demands of systematicity lie at the heart of Spinoza's philosophy too. "It is easy to reveal," he writes, "what drove him to his system: namely, the necessary striving to bring about the highest unity in human cognition." 57 Spinoza's only mistake, Fichte argues, was that "he thought to deduce on grounds of theoretical reason what he was driven to merely by a practical need." ${ }^{58}$ From this perspective what Spinoza claimed to have established on theoretical grounds was a given unity, yet what he should have done, according to Fichte, was posit this unity as a "fixed but never reachable ideal."59 Our effort to understand the unity of the pure I, Fichte tells his readers, lead us beyond the sphere of theoretical reason into the practical sphere, whereby the one absolute I is not something that exists but something "that we ought to, and yet cannot, achieve." ${ }^{60}$ In other words Fichte thinks that if we identify the apperception principle with the totality of the real, then what we have before us is not a metaphysical substratum but a normative goal. Within the aforementioned triad of principles, this means that theoretical reason cannot in the end comprehend the unity of the I and the not-I in their interdetermination. The "knot" between the two, Fichte says, "is not so much loosed as projected into infinity." ${ }^{61}$

\footnotetext{
57 Fichte, $G W L$ I:Ior.

58 Fichte, GWL 1:102.

59 Fichte, GWL I:Ior.

60 Fichte, $G W L$ I:IoI.

6I Fichte, GWL I:156.
} 


\section{Moral Perspectives \\ 4.I Persons in Kant's Moral Philosophy}

Before considering where this fateful "projection" of the I leads Fichte, it will be helpful to go back to the Paralogisms one last time and consider Kant's own effort to motivate a shift to the practical sphere. One point of interpretation I think we can now agree on is that, however much Kant wants to deflate the ambitions of rational psychology, he nevertheless intends to preserve the analytic validity of its theorems. At various points in the first Critique he hints at why this is so important. In addition to permitting a logical use, the theorems of rational psychology are also "sufficient and necessary" for a "practical use."62 Because my true nature is unknown to me, he explains, I will never be able to extend cognition to the "independence of its existence." 63 Yet for all that, "it is likewise possible that I may find cause, drawn from somewhere else than mere speculative grounds, to hope for an existence of my thinking nature that is self-sufficient and persisting through all possible changes of my state." ${ }^{34}$ In saying this Kant is alluding to the grounds people have for thinking of themselves as transcendentally free agents, grounds he believes the moral law brings directly to our attention. When I recognize a duty never to lie, for instance, I am at the same time aware of my capacity to act without sensible needs or inclinations, and so I am led, Kant argues, to a practical selfconception of the will's spontaneity. ${ }^{65}$

One might now be inclined to think that Kant is equipped with distinctly normative reasons for limiting his concept of a person to a finite noumenal substance endowed with intrinsic properties. However, it is not obvious how this line of interpretation could work. For when one considers Kant's moral argument for attributing intrinsic properties

\footnotetext{
62 Kant, $A_{3} 65$.

63 Kant, $A_{3} 8_{3}$.

64 Kant, $\mathrm{A}_{3} 83$.

65 Kant, $K p V$ 5:30; $R G V$ 6:26n.
} 
like "immateriality" to a person, it is clear that his account presupposes the analytic validity of such concepts, and so the moral argument has no role to play in their initial support. Following Kant one can say that people's awareness of the moral law justifies a conception of the will's spontaneity and with it "belief" (Glaube) that they have an independent spiritual life. ${ }^{66}$ Yet this warrant rests on a prior defense of those categories on logical grounds, which is precisely what Kant seeks to do in the first Critique. This is not a trivial point. It suggests that Kant's appeal to people's common moral consciousness only serves to give objective (albeit practical) reality to a preexisting conceptual apparatus. Consequently, if there are problems within that apparatus, such as an unjustified restriction of the I to the four theorems of rational psychology, then I cannot just retreat to whatever self-conception the moral law demands of me. To look ahead, Fichte's new way of thinking about the apperception principle, guided by the category of reciprocal interaction, leads him to reject the idea that my moral agency is intelligible as a separate "end in itself" (Zweck an sich selbst).

I raise these points to emphasize the puzzle of why Kant restricts his approach to the apperception principle, as well as to explain why the post-Kantians felt no need for such a restriction once they denied the thinkability of things in themselves. That Kant holds onto such an idea is present in his moral philosophy whenever he speaks of rational beings (in the plural) and their elevated rank above the realm of things. When one reads in the Groundwork, for example, that rational beings are called persons "because of their nature," ${ }^{67}$ it is hard to say what Kant could mean, if not that the noumenal nature of persons-their intelligence, and above all, their freedom - "marks them out" as belonging to a world beyond the senses. Relatedly, when Kant goes on to speak of a "kingdom" of rational beings interacting in community, it appears that such a community has what one might call a monadic structure, since

66 Kant, $K p V_{5}: 133$.

67 Kant, $G_{4: 428}$. 
each person (as a part) is thinkable prior to its inclusion in the community (as a whole). In this light the individual person enjoys a special "dignity," for Kant, because his capacity for self-legislation "makes him fit to be a member of a possible kingdom of ends, of which he was by his own nature already destined, as an end in itself." ${ }^{68}$ Outside this kingdom, however, he still exists like a "world apart."69

What these considerations bring to light, I believe, is that Kant is committed to a form of pluralism, both at the theoretical level in how he represents persons as finite noumenal substances, and at the practical level in how he represents persons as individual moral agents. ${ }^{70}$ These two frameworks of explanation are closely connected-more so than scholars often admit - to the extent that my self-conception as a free being presupposes the category of causality, and to the extent that my self-conception as an immortal being presupposes the category of immateriality. Thus when Kant argues that the moral law "begins from my invisible self, my personality" and in turn "reveals to me a life independent of animality and even of the whole sensible world," ${ }^{11}$ he is, I am suggesting, relying heavily on those aspects of rational psychology deemed salvageable in the Paralogisms. By contrast, as much as Fichte insists that his position in the Wissenschaftslehre is a Kantian one, I have shown that his approach to the concept of the I reveals a commitment to monism, although a monism he claims is both regulative and practical in character. In light of this contrast, then, the following question becomes urgent: What survives of "persons," if anything, once Fichte ushers in a thoroughly relational framework for philosophy, a framework that brings him closer to the company of Spinoza than to Descartes, Leibniz, or even Kant himself?

\footnotetext{
68 Kant, $G$ 4:435; see also $K U_{5}: 435$.

69 This is Leibniz's turn of phrase: "each substance is like a world apart [Monde a part], independent of all other things, except God"; Discourse on Metaphysics, ed. Roger Ariew and Daniel Garber (Indianapolis: Hackett, 1991), A 6.4, I550 = AG 47).

70 See Ameriks, "Idealism and Kantian Persons."

71 Kant, $K p V$ s:162.
} 


\subsection{Persons in Fichte's Moral Philosophy}

One might now worry that the pendulum has swung too far in the other direction, from Kant's attachment to a monadic I (and thereby to a pluralistic view of persons) to Fichte's attachment to a monistic I (and thereby to a rejection of such pluralism). However, at this stage of the discussion one should be mindful of a distinction Fichte himself draws between the I of pure self-consciousness and the I of empirical self-consciousness. What the Doctrine of Science rules out, for systematic reasons traced earlier, is the intelligibility of a thing in itself and with it the concept of an entity bearing intrinsic properties. In this admittedly technical sense Fichte's theoretical philosophy renders the idea of a person nonsensical, insofar as a person denotes an entity whose nature is thinkable in nonrelational terms (as if it were a "world apart"). To the extent that Fichte's pure I involves no empirical elements at all, it contains nothing that is unique to one particular thinker. And that is why he believes that it is suited to play the role of a first principle: as a form of self-positing activity, the pure I is unconditioned. But again, within the premises of Fichte's Wissenschaftslehre, it would be a mistake for me to assume that my access to this activity in the space of philosophical reflection indicates that my individual I is similarly unconditioned. So it would be a mistake to represent my individual I as an absolute subject, as one might think Kant is guilty of doing.

Considering this separation between the pure I and the individual I helps to show why the relational framework of the Doctrine of Science operates differently in the "Doctrine of Ethics" (Sittenlehre), which Fichte published in 1798 under the subtitle According to the Principles of the Wissenschaftslehre. As I touched on earlier, these principles proceed from the identity of the self-positing I, to the opposition of the I and the not-I, and finally, to the interdetermination of the I and the not-I (i.e., to their reciprocal interaction). In the end Fichte concludes that one is unable to comprehend on speculative grounds 
the mutually determining relation between the I and the not-I, even though, he insists, one cannot renounce the first principle and let everything depend on the not-I. The only viable solution Fichte seesand this is now the crucial point-is to regard the thought of the not-I depending on the I as an unattainable end. The path to the Doctrine of Ethics opens up as a result. For what we have before us is the end of freedom, independence, and self-sufficiency, contained in the original act of the first principle (that of absolute self-positing), except now this act has been "projected into infinity" as a practical ideal. ${ }^{72}$ In his moral philosophy Fichte's guiding question then becomes: How should I act in the sensible world, as a finite I, in such a way that I can draw closer to or "approach" (annähern) this ideal in my deeds?

My reason for calling attention to this shift in the Doctrine of Ethics is that it helps explain why Fichte applies the category of relation specifically to the individual, limited, or finite I. This shift is otherwise confusing, and as a reader one is liable to be perplexed by Fichte's announcement that consciousness of my individuality is "necessarily accompanied by another consciousness, that of a You, and is possible only on this condition," ${ }^{3}$ or that the "root of my individuality is not determined through my freedom, but through my connection with other rational beings." ${ }^{74}$ The veil of mystery surrounding such statements begins to lift when one realizes that Fichte regards the individual I as a mere mode formed by, and so initially dependent on, a nexus of relations with others. To secure this idea in his moral philosophy Fichte once more relies on the three concepts under the heading of relation, but this time his concern is with how these concepts bear upon one's particular selfhood. His central claim, which I can only

\footnotetext{
72 Fichte, GWL 1:156. For an excellent account of the path from Fichte's 1794 Wissenschaftslehre to his 1796 "Doctrine of Right," see Douglas Moggach, "Reciprocity, Elicitation, Recognition: The Thematics of Intersubjectivity in the Early Fichte," Dialogue: Canadian Journal of Philosophy 38 (1999): 271-295.

73 Fichte, $Z W E L$ i: 476.

74 Fichte, $S L$ 4: 222-223.
} 
sketch here, is that if one can discover the conditions necessary for being a particular finite self, then one can articulate a system of duties whose performance would put one closer to attaining the end of selfsufficiency. ${ }^{75}$ In the Sittenlehre Fichte develops these conditions with explicit reference to the category of relation, from the embodiment of the individual I (under the category of causality) to its intelligence (under the category of substance) and finally to its sociality (under the category of reciprocal interaction). ${ }^{76}$

The claim that sociality is a necessary condition for selfhood is itself extraordinary, since it confers transcendental status on others. Nothing like this idea is to be found in Kant, who remains committed to the rationalist school in thinking of relations with others as a merely contingent feature of selfhood. Fichte for his part is aware of this, and on one occasion he even refers to Kant's failure to warrant one's belief in the existence of others as the "most striking demonstration of the incompleteness" of his system. ${ }^{77}$ Some of Fichte's most evocative insights turn on the question of how relations with others constitute the basis of one's agency-through what he describes as a "summons" (Aufforderung), issued by another, for one to engage in free activity. It should then come as no surprise that Fichte rejects the thought that people have all the cognitive equipment they need to become aware of themselves as particular individuals. Without a summons, and so without one's awareness of another rational being (a "You"), one could not become self-conscious at all. ${ }^{78}$ In the Sittenlehre Fichte draws on this claim to give a substantive account of self-sufficiency, specifying its domain of application in the sensible world to the "entire community" outside oneself. ${ }^{79}$ With a glance back to the Wissenschaftslehre,

75 Fichte, $S L$ 4:216.

76 Fichte, $S L$ 4:216-221. For a helpful overview of these three conditions, see Hansjurgen Verweyen,

Recht und Sittlichkeit in J. G. Fichtes Gesellschaftslehre (Freiburg: Alber, 1975), 144-146.

77 Fichte, WLnm I4I-I42.

78 Fichte, GNR 3:33-37; $S L$ 4:219-220.

79 Fichte, $S L$ 4:255. 
we might say that the concept of the unlimited I as the omnitudo or "whole" of all realities at last becomes concretized in the Doctrine of Ethics, namely, as the omnitudo or "whole" of all rational beings.

While this gives the reader nothing more than a sketch, it should be clearer how deeply Fichte's monism impacts his understanding of the moral law and the practical self-conception it demands of people. In Kant's eyes, the moral law requires that each individual see herself as a separate end in herself and as an independent source of moral value, even though she is at the same time bound to act as if her maxims were to hold for other persons in a possible kingdom of ends. In Fichte's eyes, the moral law requires that each individual see herself as nothing more than an active tool or "instrument" (Werkzeug) for the community at large, and she is bound to perfect herself only insofar as doing so would make her more fit to promote the self-sufficiency of reason as such $\left(S L\right.$ 4:215).$^{80}$ One's individuality, for Fichte, enjoys no special rank or dignity, and the moral law even demands that people recognize this about themselves. "This ought to be the goal of all our thinking and acting," he writes, "and even of our individual cultivation: our final end is not ourselves but everyone." ${ }^{81}$ In this way the concept of an end in itself remains valid within Fichte's moral philosophy, but only if it refers to the totality of the social, not to the individual I. Thus, if there is room left open in the Sittenlehre for the concept of a person as free, self-sufficient, and independent, then it must refer, not to any finite thing, but to an infinite end. ${ }^{82}$

The story I have only begun to unravel in this chapter is very much a story of the rise of the concept of persons (in Kant) and its abrupt

80 Fichte, $S L$ 4:215.

8I Fichte, $S L$ 4:253; emphasis added. This is why Fichte's normative ethics amounts to a form of social perfectionism, as I have argued elsewhere: "Fichte's Normative Ethics: Deontological or Teleological?," Mind 127 (2018): 565-584.

82 Here I am indebted to Allen Wood's essay "Fichte on Freedom: The Spinozistic Background," in Spinoza and German Idealism, ed. Eckart Förster and Yitzhak Y. Melamed (Cambridge: Cambridge University Press, 2015), I2I-135. 
decline (in Fichte). In the first case, Kant's critique of rational psychology in the Paralogisms amounts to a curtailment of the metaphysical space for understanding persons. Kant thinks that if one acknowledges the limits of the human mind, one must accept that persons can never be items of strong knowledge claims, beyond how they appear under the conditions of space and time. Within the Critical system, this does not amount to a rejection of all conceptual space for persons, which Kant thinks permits both a logical use and, even more significantly, a practical use. On the grounds of people's common moral consciousness they must regard themselves as transcendentally free, and this entitles them to believe (without ever truly knowing) that they are finite noumenal substances endowed with the sort of intrinsic properties thinkers like Descartes and Leibniz ascribed to the soul. All the early post-Kantians would agree that Kant's commitment to this ontological model rests on a problematic attachment to the thing in itself. And by the time one arrives at Fichte's writings, the concept of persons as monadic entities becomes unthinkable, along with the idea that people are separate ends in themselves. It is only in Fichte's moral philosophy, I have suggested, that something like a Kantian person survives-not as the freedom, independence, and self-sufficiency of one rational being, but as the freedom, independence, and self-sufficiency of all rational beings.

\section{Abbreviations}

\section{Fichte}

GNR Grundlage des Naturrechts nach Prinzipien der Wissenschaftslehre (Foundation of Natural Right According to the Principles of the Wissenschaftslehre), 1796.

GWL Grundlage der gesammten Wissenschaftslebre (Foundation of the Entire Wissenschaftslehre), 1794.

RA "Recension des Aenesidemus" ("Review of Aenesidemus"), 1794.

Refl Reflexionen (notes written by Kant), various dates. 
SL System der Sittenlehre nach den Prinzipien der Wissenschaftslehre (System of Ethical Theory According to the Principles of the Wissenschaftslebre), 1798.

WLnm Wissenschaftslehre nova methodo (New Method of the Science of Knowledge) (student transcripts), 1796/99.

ZWEL "Zweite Einleitung in der Wissenschaftslehre" "Second Introduction to the Wissenschaftslehre"), 1797.

\section{Kant}

А/в Kritik der reinen Vernunft (Critique of Pure Reason), 1781/87. Anth Die Anthropologie in pragmatischer Hinsicht (Anthropology from a Pragmatic Point of View), 1798.

$G \quad$ Grundlegung zur Metaphysik der Sitten (Groundwork for the Metaphysics of Morals), 1785 .

Prol Prolegomena zu einer jeden künftigen Metaphysik, die als Wissenschaft wird auftreten können (Prolegomena to Any Future Metaphysics), 1783.

MS Die Metaphysik der Sitten (The Metaphysics of Morals), 1797.

PR Vorlesungen über die philosophische Religionslebre (Lectures on the Philosophical Doctrine of Religion) (student transcripts), 1783-84.

KpV Kritik der praktischen Vernunft (Critique of Practical Reason), 1788.

KU Kritik der Urteilskraft (Critique of the Power of Judgment), 1790 .

\section{Schelling}

FP Über die Möglichkeit einer Form der Philosophie überhaupt (On the Possibility of a Form of Philosophy in General), 1794. IP Vom Ich als Princip der Philosophie oder über das Unbedingte im menschlichen Wissen (Of the I as the Principle of Philosophy or On the Unconditioned in Human Knowledge), 1795. 
